\title{
Bio-environment Designing for Cartilage-regeneration Using Stem Cells
}

\author{
○門林 義幸（京大院） 正 山本 浩司（京大院）山本 英郎（京大工） \\ 中嶋 正明（京大院） 脇谷 滋之（信州大） 正 富田 直秀（京大院）
}

Yoshiyuki KADOBAYASHI, Kyoto University, Yoshida-honmachi, Sakyo-ku, Kyoto Koji YAMAMOTO, Kyoto University Hideo YAMAMOTO, Kyoto University Masaaki NAKAJIMA, Kyoto University Shigeyuki WAKITANI, Shinshu University Naohide TOMITA, Kyoto University

\begin{abstract}
Living tissue maintains its shape and function by adaptive self-remodeling in the environment. Our theme is the "in-vivo environment designing" which thought to be the key factor for successful tissueengineering treatment. In previous reports, significance of the environment designing was showed using ES-cells transplanting into knee joint. In this report, change in viability of cells under low-temperature and/or high-pressure condition was evaluated. The high-pressure condition was set by hydrostatic-pressure apparatus using controlled piston mechanism. The results suggested the presence of some environmentderived communicative matter, but not yet have proved.
\end{abstract}

Key Words : Stem Cell, Cartilage Regeneration, Physical Stimulation, Bio-environment designing.

\section{は じめ に}

再生医療が目指す目標の一つに，必要とされる組織の 形態形成および機能発現がある. 近年着目されている組 織再生治療法の一つは, 幹細胞の有する多能性および自 己複製能を利用したものである.しかし，幹細胞が特定 の細胞に分化し組織化するためには外・内部の環境との 相互作用が重要であり，環境を含みこんだシステムを考 慮する必要がある.

我々は細胞または組織周辺の物理環境を設定すること によって，機能的な組織を得る「生体環境設計」を提唱 し，基礎実験及び臨床応用を進めている，そこで，環境 の設定条件の効率的設計を行うためには, 生体の多様性 と自律性を考慮した思考ツールが必要であり，一連の組 織化過程を情報の流れとしたモデルを in silico で構築し $た^{(1)}$ ，その中で，環境変化に関する情報のフィードバッ クが形態や機能発現の効率化に影響を与えている事が示 唆された．本稿では，細胞間での環境変化に関する情報 の受け渡しの有無を調べるべく，低温環境, 静水圧環境 が及ぼす影響をそれぞれ検証した。

\section{1. 実 験 方 法}

1.1 実験装置 Fig. 1, 2 に加圧装置の写真及び, そ の概略を示す. サーボモータ（AIP4150-AM オリエン タルモータ社製）によりピストンを駆動し，加圧速度は プログラムにより制御した. 圧力計には耐環境型デジタ ル圧力センサ (AP-V80・AP-16S キーエンス社製)を用 い, 出力電圧值をマイクロコンピュータ $(\mathrm{h} 83069 \mathrm{f}$ ルネ サステクノロジー社製) により処理し，サーボモータを 駆動する．加圧時の圧力の誤差は $\pm 0.2 \mathrm{MPa}$ である．ま た, 清潔な状態で細胞に静水圧を加えるために, 冷凍保 存用クライオチューブ (NALGENENL クライオチューブ

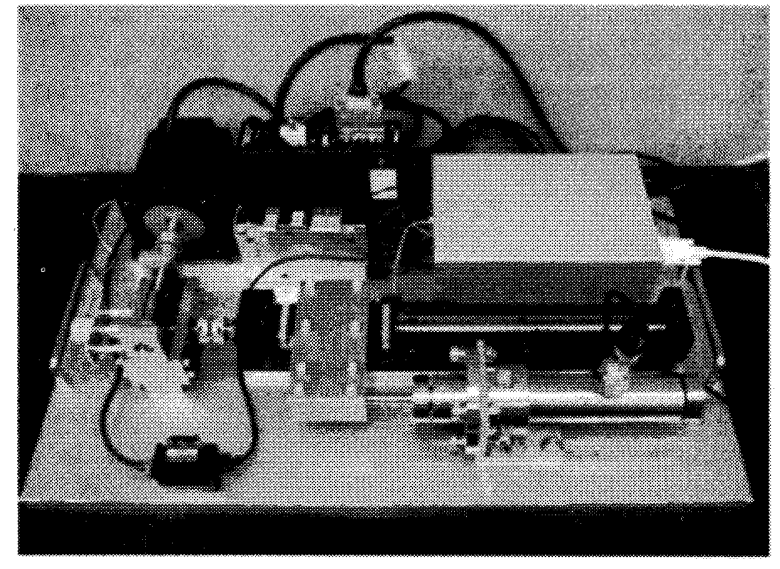

Fig. 1 Photograph of experimental system

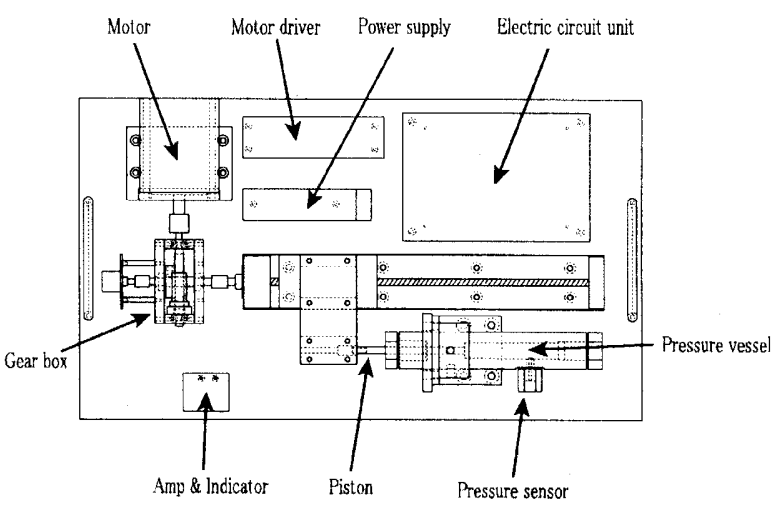

Fig. 2 Schematic drawing of experimental apparatus

2ml）に細胞を DMEM と共に入れ，空気が入らないよう に蓋をする(2). クライオチューブの内と外で圧力が同じ であることを調べるため感圧フィルム（プレスケール低 圧用 富士フイルム社製) を用い検証したところ, 誤差 
は 10\%以内であることがわかった.

1.2 試料 ラット脂肪由来の間質細胞 (AMSC) ${ }^{(3)}$ 継代数 3〜5 の細胞を用いた. 細胞活性測定法としてニ ユートラルレッド染色を使用し吸光度を計測した.

1.3 低温環境実験 $\quad \phi 100 \mathrm{~mm}$ CultureDish にコンフ ルエント状態の細胞を低温環境 $\left(7^{\circ} \mathrm{C} \cdot\right.$ 遮光室・ $\mathrm{CO}_{2}$ 濃 度無調整）に 36 時間さらし，その上澄みを新たに細胞を 播種して 12 時間後のディッシュの培地と交換した. 交換 したディッシュを同様の操作で低温環境下に 36 時間置い た. コントロール群として低温環境下に無血清 DMEM の上澄みを入れたディッシュを 36 時間置き活性を測った.

1.4 加圧試験クライオチューブへ細胞濃度 $1.0 \times$ $10^{5} \mathrm{cells} /$ tube の緗胞浮遊液の状態で封入し加圧した. コン トロール群として, 同濃度の細胞混濁液を封入したチュー ブを被静水圧チューブと同じ姿勢で圧力容器外に静置し た. 実験は室温環境下 $\left(25 \pm 2{ }^{\circ} \mathrm{C}\right)$ で行った.

まず圧力環境が細胞に及ぼす影響を細胞活性の変化に より計測した. まず AMSC をクライオチューブに入れ 24 時間 $15 \mathrm{MPa}$ 静水圧を加え活性変化を検証した.

次に AMSC をクライオチューブに入れ 24 時間 $15 \mathrm{MPa}$ 静水圧を加えた後, この上澄み $2.0 \mathrm{ml}$ と $\mathrm{DMEM}+10 \% \mathrm{FCS} 5 \mathrm{ml}$ を混合した培地を細胞播種後 24 時 間のディッシュの上澄みと交換した. コントロール群と して加圧容器の外に細胞を入れたクライオチューブを 24 時間置き,この上澄みを加圧上澄みと同様にディッ シュに入れた後, 24 時間インキュベータ内で培養して 活性を測った.

\section{2. 結果及び考察}

2.1 低温環境での細胞活性 $\quad 36$ 時間 $7{ }^{\circ} \mathrm{C}$ 低温環境 下で静置した後の細胞活性を Fig. 3(a)に示す.この結果 より，低温環境により細胞はダメージを受け，細胞活性 が低下した事がわかる.

2.2 低温上澄み添加実験上澄みを添加する実験 によって得られた結果を Fig. 3(b) に示す. 低温環境下で 細胞が培養された上澄みを加えた方が細胞活性を向上さ せる結果となった。

2.3 加圧後の細胞活性 24 時間 15MPa 加圧後の細 胞活性を Fig. 4(a) に示す.この結果より, 圧力により細 胞はダメージを受け, 細胞活性が低下した事がわかる.

2.4 加圧上澄み添加実験上澄みを添加する実験 によって得られた結果を Fig. 4(b) に示す. 加圧後の上澄 みを加えた方が細胞活性が低下する結果となった.

なお, 培地のみをそれぞれの環境に暴露しその上澄み を加えて間質細胞に加えた場合は変化は見られなかった。 Fig. 3(a), Fig. 4(a)に示す結果より細胞は物理環境によっ てダメージを受け, 活性が低下している事がわかる. その 上澄みをかけ再度同一環境下で実験すると, 低温刺激の

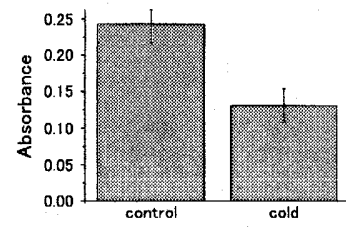

(a)

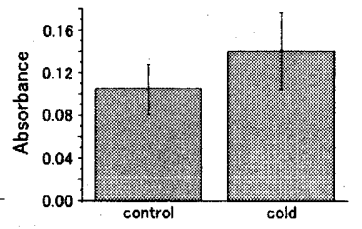

(b)
Fig. 3 Viability Of Cells Under Lo-Temperature Environment

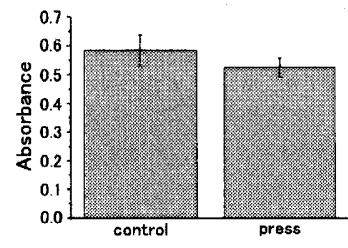

(a)

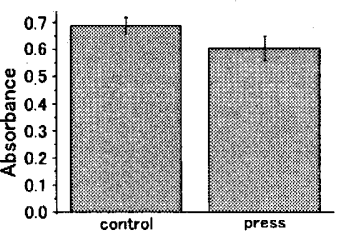

(b)
Fig. 4 Viability Of Cells Under High-Pressure Environment

実験では細胞の活性が向上する結果が示され (Fig. 3(b)), 圧力刺激を与える実験では細胞の活性が低下する結果と なった (Fig. 4(b)). これより, 物理的刺激として温度や 圧力を加えられた際に何らかの環境に依存した情報の伝 達機能があるのではないかと推測することができる.

$$
\text { おわりに }
$$

生体が物理環境の変化に効率的に適応するためには, 物理環境の変化に応じた何らかの情報伝達が必要となる. 本実験ではその伝達物質をさがすための基礎検討として, 圧力及び温度変化に応じた間質細胞の活性変化と変化に 曝された細胞培養上澄み液の間質細胞に及ぼす変化を調 べた. 高圧下に置かれた細胞上澄み液は細胞の圧力に対 する耐性を低下させ，また，低温下におかれた細胞上澄 み液は低温に対する耐性を上昇させた. 現在のところそ れぞれの物理環境に対する交差試験は実施していないた め，それぞれの物理環境に応じた情報物質存在の可能性 は検証されていない。

$$
\text { 文献 }
$$

（1）山本浩司，富田直秀，他”骨軟骨再生のための生体環境 設計”, 計測自動制御学会システム・情報部門学術講演会 2004 講演論文集, pp.197-202，2004

(2) P.Angele, J.U.Yoo, et al " Cyclic hydrostatic pressure enhances the chondrogenic phenotype of human mesenchymal progenitor cells differentiated in vitro", J.Orthopaedic Res., Vol.21, pp.451-457, 2003

（3）水野博司 "幹細胞供給源としての脂肪組織の有用性", J Nippon Med Sch, 70(5), pp.428-431， 2003 